\title{
Progressive outer retinal necrosis in a multiple sclerosis patient on natalizumab
}

Figure 1 Fundus photographs of both eyes at presentation
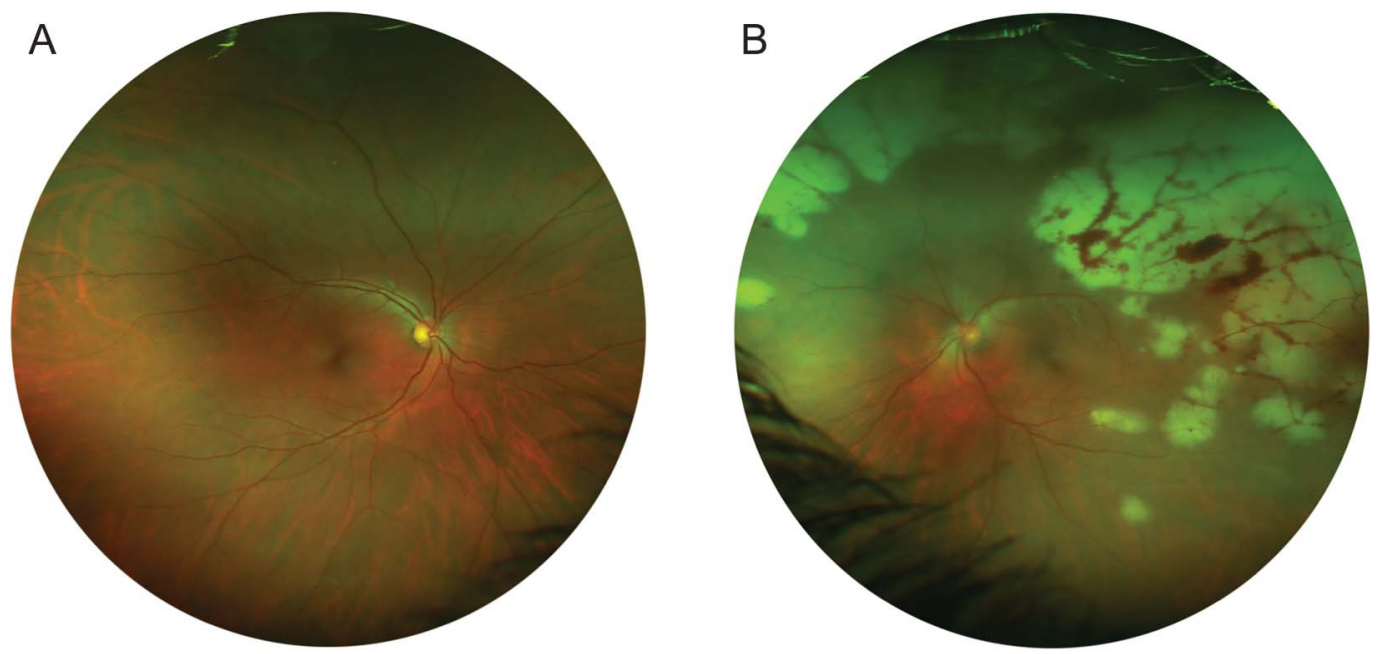

Normal right fundus with 20/20 visual acuity (A); peripheral confluent retinal whitening, hemorrhages, and vasculitis in left eye with $20 / 125$ visual acuity (B).

A 54-year-old woman with multiple sclerosis, on natalizumab, reported 2 weeks of left eye redness and blurry vision, previously diagnosed as conjunctivitis. Visual acuity was 20/125. Funduscopy revealed progressive outer retinal necrosis (figure 1), a viral retinitis of immunocompromised patients that frequently causes vision loss. ${ }^{1}$ Sequential bilateral involvement is common. Etiologies include varicella zoster, herpes simplex, and rarely cytomegalovirus; aqueous PCR revealed varicella. Natalizumab was held. IV and intravitreal antivirals were administered. After repair of retinitis-induced retinal detachment and resolution of retinitis, visual acuity was 20/125 (figure 2). In immunocompromised patients with ocular symptoms, clinicians should consider infectious retinitis and obtain prompt funduscopic evaluation.

Sarah Haseltine Van Tassel, MD, Mrinali P. Gupta, MD, Anton Orlin, MD, Nancy M. Nealon, MD,

Sarju S. Patel, $M D$

From Weill Cornell Medical College, New York, NY.

Author contributions: Sarah Haseltine Van Tassel: drafting/revising the manuscript, study concept or design, analysis or interpretation of data, accepts responsibility for conduct of research and final approval. Mrinali Patel Gupta: drafting/revising the manuscript, study concept or design, accepts responsibility for conduct of research and final approval, acquisition of data. Anton Orlin: drafting/revising the manuscript, study concept or design, accepts responsibility for conduct of research and final approval. Nancy M. Nealon: analysis or interpretation of data, accepts responsibility for conduct of research and final approval, study supervision. Sarju S. Patel: drafting/ revising the manuscript, accepts responsibility for conduct of research and final approval, acquisition of data.

Study funding: No targeted funding reported.

Disclosure: S. Van Tassel receives support from Research to Prevent Blindness. M. Gupta receives support from Research to Prevent Blindness. A. Orlin receives support from Research to Prevent Blindness. N. Nealon reports no disclosures relevant to the manuscript. S. Patel receives support from Research to Prevent Blindness. Go to Neurology.org for full disclosures.

Correspondence to Dr. Patel: sap9067@med.cornell.edu

1. Gore DM, Gore SK, Visser L. Progressive outer retinal necrosis: outcomes in the intravitreal era. Arch Ophthalmol 2012;130: $700-706$. 


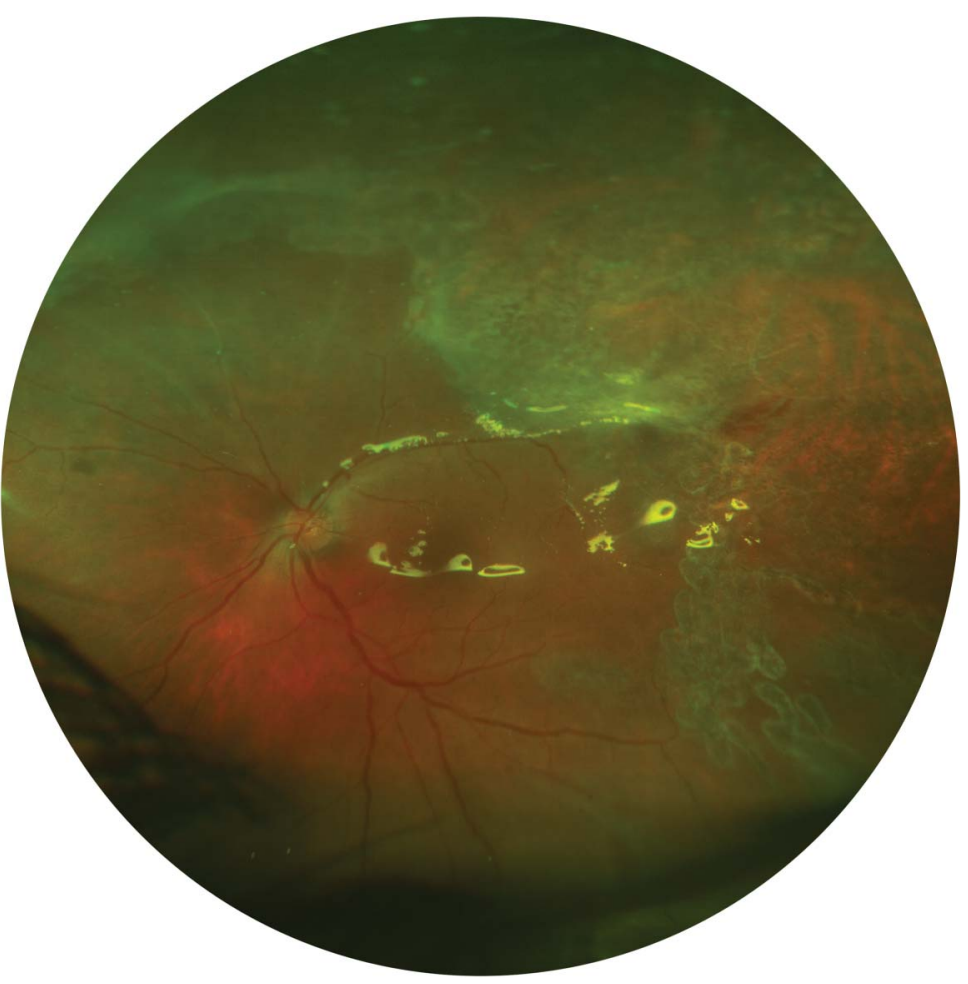

After 2 months of biweekly intravitreal injections, 1 month of IV antivirals and ongoing oral antivirals, and retinal detachment surgeries, the left retina was attached with resolved retinitis.

\section{Visit the Neurology ${ }^{\circledR}$ Web Site at Neurology.org}

- Enhanced navigation format

- Increased search capability

- Highlighted articles

- Detailed podcast descriptions

- RSS Feeds of current issue and podcasts

- Personal folders for articles and searches

- Mobile device download link

- AAN Web page links

- Links to Neurology Now ${ }^{\circledR}$, Neurology Today ${ }^{\circledR}$, and Continuum ${ }^{\circledR}$

- Resident \& Fellow subsite

(n) Find Neurology ${ }^{\circledR}$ on Facebook: http://tinyurl.com/neurologyfan

twitter Follow Neurology ${ }^{\circledR}$ on Twitter: https://twitter.com/GreenJournal 


\section{Neurology}

\section{Progressive outer retinal necrosis in a multiple sclerosis patient on natalizumab Sarah Haseltine Van Tassel, Mrinali P. Gupta, Anton Orlin, et al. Neurology 2015;84;2198-2199 \\ DOI 10.1212/WNL.0000000000001611}

This information is current as of May 25, 2015

\section{Updated Information \& Services}

References

Citations

Subspecialty Collections

Permissions \& Licensing

Reprints including high resolution figures, can be found at: http://n.neurology.org/content/84/21/2198.full

This article cites 1 articles, 0 of which you can access for free at: http://n.neurology.org/content/84/21/2198.full\#ref-list-1

This article has been cited by 1 HighWire-hosted articles: http://n.neurology.org/content/84/21/2198.full\#\#otherarticles

This article, along with others on similar topics, appears in the following collection(s):

Multiple sclerosis

http://n.neurology.org/cgi/collection/multiple_sclerosis

\section{Retina}

http://n.neurology.org/cgi/collection/retina

Viral infections

http://n.neurology.org/cgi/collection/viral_infections

Visual loss

http://n.neurology.org/cgi/collection/visual_loss

Information about reproducing this article in parts (figures,tables) or in its entirety can be found online at:

http://www.neurology.org/about/about_the_journal\#permissions

Information about ordering reprints can be found online:

http://n.neurology.org/subscribers/advertise

Neurology ${ }^{\circledR}$ is the official journal of the American Academy of Neurology. Published continuously since 1951, it is now a weekly with 48 issues per year. Copyright @ 2015 American Academy of Neurology. All rights reserved. Print ISSN: 0028-3878. Online ISSN: 1526-632X.

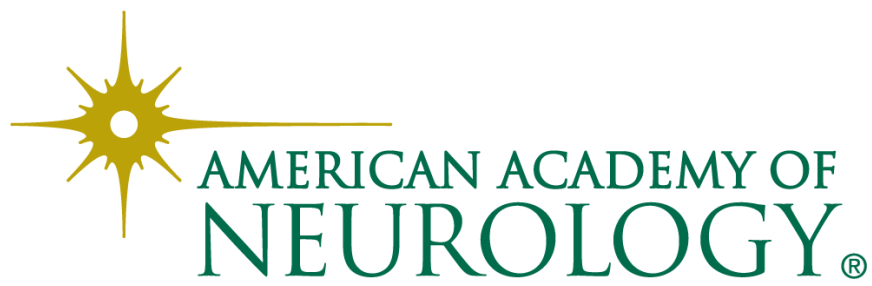

